OPEN ACCESS

Edited by:

Qian Li,

Guangzhou University, China

Reviewed by:

Satarupa Dey,

University of Calcutta, India

Zengpeng $\mathrm{Li}$,

State Oceanic Administration, China

*Correspondence:

Ran Zhao

zhaoran@xmu.edu.cn

tThese authors have contributed equally to this work

Specialty section: This article was submitted to Microbiotechnology,

a section of the journal

Frontiers in Microbiology

Received: 23 November 2021

Accepted: 14 February 2022

Published: 03 March 2022

Citation:

An Q, Zhang M, Guo D, Wang G, $X u H$, Fan C, Li J, Zhang W, Li Y, Chen $X$, You W and Zhao $R$ (2022)

Cr(VI) Removal by Recombinant Escherichia coli Harboring the Main

Functional Genes of Sporosarcina saromensis M52.

Front. Microbiol. 13:820657.

doi: 10.3389/fmicb.2022.820657

\section{Cr(VI) Removal by Recombinant Escherichia coli Harboring the Main Functional Genes of Sporosarcina saromensis M52}

\author{
Qiuying $\mathrm{An}^{1 \dagger}$, Min Zhang ${ }^{2 \dagger}$, Dongbei Guo ${ }^{1}$, Guangshun Wang ${ }^{1}$, Hao Xu', Chun Fan', \\ Jiayao Li $^{3}$, Wei Zhang ${ }^{1}$, Yi Li ${ }^{1}$, Xiaoxuan Chen ${ }^{1}$, Wanting You' ${ }^{1}$ and Ran Zhao ${ }^{1 *}$ \\ 'State Key Laboratory of Molecular Vaccinology and Molecular Diagnostics, School of Public Health, Xiamen University, \\ Xiamen, China, ${ }^{2} H u z h o u$ Center for Disease Prevention and Control, Huzhou, China, ${ }^{3}$ National Cancer Center/National \\ Clinical Research Center for Cancer/Cancer Hospital \& Shenzhen Hospital, Chinese Academy of Medical Sciences and \\ Peking Union Medical College, Shenzhen, China
}

Hexavalent chromium [Cr(VI)], a recognized heavy metal pollutant, has attracted much attention because of its negative impact on the ecological environment and human health. A chromium-resistant strain, Sporosarcina saromensis M52, was discovered, and the functional genes orf2987, orf3015, orf0415, and orf3237 were identified in the strain by genomics. With the advancement of DNA recombination and gene-splicing technology, genetic engineering technology was used to produce recombinant strains 2987, 3015, 0415, and 3237. The study revealed $\mathrm{Cr}(\mathrm{VI})$ tolerance in the order of $M 52 \approx 2987>3015 \approx 0415>3237$ and reduction abilities in the order of M52 $\approx 2987>3015>0415 \approx 3237$. SEM-EDS, XRD, FT-IR and XPS were utilized to examine the surface structure of the recombinant strains and analyze the surface components and main functional groups. A comprehensive review of the recombinant strains' capacity to tolerate and reduce $\mathrm{Cr}(\mathrm{VI})$ revealed that orf2987 and orf0415 were the main functional genes in Sporosarcina saromensis M52, which may play a key role in removing $\mathrm{Cr}(\mathrm{VI})$ and protecting the strain, respectively. The optimum $\mathrm{pH}$ for recombinant strains 2987 and 0415 was $7.5-8.5$, and the optimum temperature was $37^{\circ} \mathrm{C}$. $\mathrm{Cu}^{2+}$ had the greatest promotional effect when $\mathrm{Cr}(\mathrm{VI})$ was removed by them, while SDS had an inhibitory effect. This research provided the foundation for further study into the mechanism of $\mathrm{Cr}(\mathrm{VI})$ reduction in Sporosarcina saromensis M52, as well as a theoretical basis for the development of effective engineered strains to repair $\mathrm{Cr}(\mathrm{VI})$ contamination.

Keywords: Sporosarcina saromensis M52, recombinant bacteria, hexavalent chromium, $\mathrm{Cr}(\mathrm{VI})$ reduction, bioremediation 


\section{INTRODUCTION}

With the rapid development of industry, chromium (Cr) has been widely used in electroplating, wood preservation, material dying, leather tanning and other industries, and associated industrial effluents pose a serious threat to ecology and human health (Stern, 2010; Malaviya and Singh, 2016; Diaconu et al., 2020). The oxidation state of $\mathrm{Cr}$ varies from -2 to +6 , in which trivalent chromium [ $\mathrm{Cr}(\mathrm{III})]$ and hexavalent chromium [Cr(VI)] are the main forms in water (Thatoi et al., 2014). $\mathrm{Cr}(\mathrm{III})$ is a necessary trace element for the human body (Karthik et al., 2017; Ma et al., 2019), whereas $\mathrm{Cr}(\mathrm{VI})$ has been proven to have carcinogenicity, teratogenicity, and mutagenicity (Xia et al., 2019). Since the toxicity of $\mathrm{Cr}(\mathrm{VI})$ is 100 times higher than that of $\mathrm{Cr}$ (III) (Xia et al., 2019; Gu et al., 2020), converting $\mathrm{Cr}(\mathrm{VI})$ to $\mathrm{Cr}(\mathrm{III})$ becomes the main strategy to address $\mathrm{Cr}(\mathrm{VI})$ pollution.

The main ways to reduce $\mathrm{Cr}(\mathrm{VI})$ to $\mathrm{Cr}(\mathrm{III})$ are physical, chemical, and biological remediation methods (Nayak et al., 2020). Many physical and chemical methods, such as membrane separation, chemical precipitation, ion exchange, and electrochemical methods, are currently used, but they often have the disadvantages of being expensive, taking a long time, requiring a large amount of reagents, and eventually producing a large number of secondary pollutants that are difficult to deal with (Agrawal et al., 2006; Barrera-Diaz et al., 2012; Bvrith and Reddy, 2013; Jobby et al., 2018). However, when compared to these traditional physical and chemical remediation methods, bioremediation has the unique advantages of being simple to operate, low in cost, requiring fewer reagents, and producing fewer secondary pollutants, giving it the potential to become an environmentally friendly chromium remediation technology (Harish et al., 2012; Bharagava and Mishra, 2018). Many strains, such as Bacillus, Pseudochrobactrum, Brevibacterium, Stenotrophomonas, Vigribacillus, Ochrobactrum, and Cellulosimicrobium strains (Karthik et al., 2017; Banerjee et al., 2019), have been discovered to be able to tolerate and decrease $\mathrm{Cr}(\mathrm{VI})$ in recent decades. Sporosarcina saromensis M52 (M52), collected in Xiamen, also has the ability to effectively decrease $\mathrm{Cr}(\mathrm{VI})$, although the mechanism was unclear (Zhao et al., 2016). In previous studies, the functional genes of M52 were identified by genomic analysis (Li et al., 2021), which identified orf2987, orf3015, orf0415, and orf3237 as the major functional genes in M52, mainly responsible for reducing $\mathrm{Cr}(\mathrm{VI})$, but whether they really have the function of reducing $\mathrm{Cr}(\mathrm{VI})$ has not been confirmed.

With the advancement of DNA recombination and genesplicing technology, genetic engineering technology can be used to construct recombinant strains that can verify the functions of orf2987, orf3015, orf0415, and orf3237. In the process of constructing, Escherichia coli BL21 (E. coli) is a suitable carrier for the following reasons: (1) E. coli has a very defined genetic background and has been authorized by the FDA as a safe genetically engineered recipient organism. (2) The culture technique for E. coli is simple, with rapid growth, a short culture period, good anti-pollution ability, and a low cost. (3) It has a mature and complete expression system capable of efficiently expressing the target protein (Ke et al., 2018). (4)
It is the most widely used strain in research and industry and has been extensively studied (Jaen et al., 2019). (5) The reduction capacity of $\mathrm{Cr}(\mathrm{VI})$ is very weak (Guo et al., 2012).

In this research, the recombinant strains were created to verify and compare the reduction characteristics and tolerance of orf2987, orf3015, orf0415, and orf3273 in M52 to $\mathrm{Cr}(\mathrm{VI})$, as well as to screen out the key functional genes that play reducing and protective roles in M52. Via a laboratory simulation of the $\mathrm{Cr}(\mathrm{VI})$-contaminated environment, the optimum conditions of recombinant strains containing key functional genes were determined for improved $\mathrm{Cr}(\mathrm{VI})$ reduction, and their functional groups in the reduction process were also detected. This research not only confirmed that orf2987, orf3015, orf0415, and orf3237 in M52 had reduction characteristics and tolerance to $\mathrm{Cr}(\mathrm{VI})$ but also provided the foundation for future research into the mechanism of reducing $\mathrm{Cr}(\mathrm{VI})$ in Sporosarcina saromensis M52, as well as a theoretical basis for the creation of engineering strains with high efficiency to remediation $\mathrm{Cr}(\mathrm{VI})$ pollution.

\section{MATERIALS AND METHODS}

\section{orf 2987, orf3015, orf0415, and orf3237 Genes}

M52 was inoculated in $\mathrm{LB}$ medium at $37^{\circ} \mathrm{C}$ and cultivated at $200 \mathrm{rpm}$ for $15 \mathrm{~h}$ after being revived. The TIANamp Bacteria DNA Kit was used to extract the genome. After extracting the M52 genome, BLAST $\mathrm{p}$ was aligned and annotated by the $\mathrm{Nr}$, Swiss-Prot, Pfam, String, COG/KOG, KEGG, and GENE Ontology databases, and the orf2987, orf3015, orf0415, and orf3237 gene sequences were obtained. Special PCR primers (Supplementary Table S1) for cloning the orf2987, orf3015, orf0415, and orf3237 genes were designed by Primer Premier 5.0 and synthesized by Sangon Biotech (Shanghai, China). In the PCR experiment, we used $2 \times P f u$ fidelity mixing enzyme (Tiangen Biotech Co., Ltd., Beijing, China) to ensure correct cloning of the gene series. All PCR-amplified products were separated and identified by $1.5 \%$ agarose gel electrophoresis and recovered by the TIANgel Universal DNA Purification Kit (Tiangen Biotech Co., Ltd., Beijing, China).

\section{Construction of Recombinant Strains}

In this experiment, pET-30a(+), which containing kanamycin resistance gene, was used as the expression vector for recombinant strains. The plasmid was extracted by the TIANprep Mini Plasmid Kit (Tiangen Biotech Co., Ltd., Beijing, China). The target genes orf2987, orf3015, orf0415, and orf3237 were subjected to double enzyme cutting by restriction enzymes (listed in Supplementary Table S1). After purification and connection, the orf2987, orf3015, orf0415, and orf3237 genes were combined with pET-30a $(+)$ to produce recombinant vectors pET-2987, pET-3015, pET-0415 and pET-3237. Recombinant vectors were converted into $E$. coli BL21 (DE3) to create recombinant strains $2987,3015,0415$, and 3237 . Positive clone plasmids screened with a solid selective LB plate containing $50 \mu \mathrm{g} / \mathrm{ml}$ kanamycin were extracted and then confirmed by enzyme digestion and sequencing. 


\section{Expression and Localization of Recombinant Proteins}

Recombinant strains 2987, 3015, 0415, and 3237, were grown in $\mathrm{LB}$ medium with kanamycin $(50 \mu \mathrm{g} / \mathrm{ml})$ at $37^{\circ} \mathrm{C}$. The strains were centrifuged at $4,000 \mathrm{rpm}$ for $10 \mathrm{~min}$, the supernatant was discarded, and the bacteria were suspended with $500 \mu \mathrm{l}$ of bacterial lysate. After being washed and disrupted with $50 \mathrm{mM}$ Tris- $\mathrm{HCl}$, the strains were disrupted by ultrasonication for a total of $6 \mathrm{~min}(300 \mathrm{~W}$, ultrasound for $0.5 \mathrm{~s}$, period for $5 \mathrm{~s})$ in an ice bath and centrifuged at $12,000 \mathrm{rpm}$ for $20 \mathrm{~min}$ at $4^{\circ} \mathrm{C}$. Supernatant and precipitate were used as samples where precipitation was dissolved in a $500 \mu \mathrm{l}$ inclusion body solution ( $8 \mathrm{mM}$ urea, $50 \mathrm{mM}$ Tris- $\mathrm{HCl}, 300 \mathrm{mM} \mathrm{NaCl}, \mathrm{pH}$ 8.0). Expressed recombinant proteins were identified by $10 \%$ sodium dodecyl sulfate-polyacrylamide gel electrophoresis (SDS-PAGE).

\section{Cr-Resistance and Cr-Reduction Characteristics of Recombinant Strains Growth Curve of Strains}

M52 and recombinant strains were cultured overnight for $14-16 \mathrm{~h}$ at $37^{\circ} \mathrm{C}$ and $200 \mathrm{rpm}$. The culture was then stopped and the seed liquid was prepared. The cultured $4 \% \mathrm{v} / \mathrm{v}$ seed liquid was inoculated into LB medium with and without $\mathrm{Cr}(\mathrm{VI})$. At different times, the A600 of the bacterial liquid was calculated by a full-wavelength enzyme labeling instrument, and the growth curve was drawn under $\mathrm{Cr}(\mathrm{VI})$-free and $\mathrm{Cr}(\mathrm{VI})$ containing conditions.

\section{Resistance to $\mathrm{Cr}(\mathrm{VI})$}

M52 and recombinant strains were shaken and cultured at $37^{\circ} \mathrm{C}$ overnight. The strains were obtained by centrifugation and calibrated to the same concentration as A600. After washing with PBS three times, the strain was resuspended in sterilized LB medium containing various concentrations of $\mathrm{Cr}(\mathrm{VI})(0$, $50,100,200,400$, and $800 \mathrm{mg} / \mathrm{L})$ at $\mathrm{pH} 8.0$ and cultured at $37^{\circ} \mathrm{C}$ and $200 \mathrm{rpm}$ for $72 \mathrm{~h}$. The A600 of the bacterial solution was tested every $12 \mathrm{~h}$, and a growth curve was drawn to determine the $\mathrm{Cr}(\mathrm{VI})$ tolerance of the strains.

\section{Reduction of $\mathrm{Cr}(\mathrm{VI})$}

After cultivating strains in sterilized LB medium containing various concentrations of $\mathrm{Cr}(\mathrm{VI})(0,50,100,200,400$, and $800 \mathrm{mg} / \mathrm{L})$, the colonies were centrifuged at $12,000 \mathrm{rpm}$ at $4^{\circ} \mathrm{C}$ for $20 \mathrm{~min}$ twice. Supernatants were purified using $0.22 \mu \mathrm{m}$ filters (Millipore, United States) to eliminate the remaining bacterial cells. The $\mathrm{Cr}(\mathrm{VI})$ content of the supernatant of the culture medium at different times was calculated by the diphenylcarbazide spectrophotometry method. At the beginning of the experiment, the A540 of the solution containing $\mathrm{Cr}(\mathrm{VI})$ was recorded as $A_{0}$, the $A 540$ of the solution to be evaluated was labeled as $A_{1}$, and the A540 solution without $\mathrm{Cr}(\mathrm{VI})$ was recorded as $\mathrm{C}$. The reduction percentage of the strain to $\mathrm{Cr}(\mathrm{VI})$ at the time to be tested was calculated by the following formula:

$$
X=\frac{A_{0}-A_{1}}{A_{0}-C} \times 100 \%
$$

\section{Characterization of $\mathrm{Cr}(\mathrm{VI})$ Reduction SEM-EDS Analysis}

The surface morphology of the strains before and after the reduction of $\mathrm{Cr}(\mathrm{VI})$ was characterized by the use of a ZEISS Sigma Scanning Electron Microscope (SEM) fitted with an Energy Dispersive spectroscopy (EDS). The strains were cultivated in sterilized $\mathrm{LB}$ medium ( $\mathrm{pH} 8.0$ ) with $100 \mathrm{mg} / \mathrm{L} \mathrm{Cr}(\mathrm{VI})$ at $37^{\circ} \mathrm{C}$

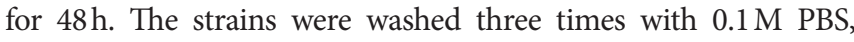
and the suspension was scattered over a glass slide and dried. Samples of immobilized strain were prepared according to the method of Garg et al. (2013). After spraying the gold, position the sample into the SEM-EDS unit, examine the different sections of the sample under an accelerating voltage of $15 \mathrm{kV}$, and then take micrographs under appropriate magnification.

\section{XRD, FT-IR, and XPS Analysis}

Fourier Transform Infrared Spectroscopy (FT-IR) and X-ray photoelectron spectroscopy (XPS) were used to record the process of chemical modification of strains before and after reduction of $\mathrm{Cr}(\mathrm{VI})$ to study the functional group responsible for reducing the surface area of strains. X-ray diffraction (XRD) analysis was performed on the control and $\mathrm{Cr}(\mathrm{VI})$-treated strains to identify the crystallized $\mathrm{Cr}(\mathrm{III})$ species during the $\mathrm{Cr}(\mathrm{VI})$ reduction process. The strains were cultured in sterilized LB medium in the presence and absence of $100 \mathrm{mg} / \mathrm{L} \mathrm{Cr}(\mathrm{VI})$. After $48 \mathrm{~h}$ of incubation, the cultivated strains were washed with PBS, extracted by centrifugation, and then lyophilized in a vacuum freezer dryer (Ma et al., 2019). FT-IR, XPS and XRD were all performed at the SLIntelligent Analysis Testing Center (Nanjing, China).

\section{Factors Affecting $\mathrm{Cr}(\mathrm{VI})$ Reduction $\mathrm{pH}$ and Temperature}

The effects of various $\mathrm{pH}$ values $(7.0,7.5,8.0,8.5$, and 9.0) and incubation temperatures $\left(25,30,35,40\right.$, and $\left.45^{\circ} \mathrm{C}\right)$ on $\mathrm{Cr}(\mathrm{VI})$ reduction in the strains were tested with $100 \mathrm{mg} / \mathrm{L}$ $\mathrm{Cr}(\mathrm{VI})$. Using a factorial design, each temperature level and $\mathrm{pH}$ level were completely randomly combined, and there were 25 groups in total, with three parallel samples in each group. All centrifuge tubes were placed in a constant temperature shaker at $200 \mathrm{rpm}$ for $48 \mathrm{~h}$. The culture was removed from each treatment at 12,24, and $48 \mathrm{~h}$ and centrifuged twice at $4^{\circ} \mathrm{C}$ and $12,000 \mathrm{rpm}$ for $20 \mathrm{~min}$. The supernatant was then screened with a $0.22 \mu \mathrm{m}$ filter (Millipore, United States) to eliminate the remaining bacterial cells. The $\mathrm{Cr}(\mathrm{VI})$ content of the culture supernatant was determined at different times to measure the $\mathrm{Cr}(\mathrm{VI})$ reduction percentage.

\section{Metal Ions and Small Molecules}

Cultured $4 \% \mathrm{v} / \mathrm{v}$ seed liquid was inoculated into LB medium containing $100 \mathrm{mg} / \mathrm{L} \mathrm{Cr}(\mathrm{VI})$ with $0.2 \mathrm{mM} \mathrm{Mn}{ }^{2+}, \mathrm{Fe}^{2+}$, and $\mathrm{Cu}^{2+}$, which were all made with sulphates, and $0.1 \mathrm{mM}$ SDS. The $100 \mathrm{mg} / \mathrm{L} \mathrm{Cr}(\mathrm{VI})$ bacterial solution without metal ions and small molecular compounds was used as a control. All centrifuge tubes were cultured at $\mathrm{pH} 8.0,37^{\circ} \mathrm{C}$ and $200 \mathrm{rpm}$ for $48 \mathrm{~h}$, and the cultures were regularly separated from each procedure every $12 \mathrm{~h}$ and centrifuged at $12,000 \mathrm{rpm}$ for $20 \mathrm{~min}$. The 
supernatant was then filtered with a $0.22-\mu \mathrm{m}$ filter (Millipore, United States) to remove the remaining bacterial cells. The $\mathrm{Cr}(\mathrm{VI})$ content in the culture supernatant was determined at different times to ascertain the $\mathrm{Cr}(\mathrm{VI})$ reduction percentage.

\section{Statistical Analysis}

Statistical analysis of all experimental results was performed using SPSS 23.0 test, where $p<0.05$ indicates that the discrepancy is statistically important. Because the experimental data for resistance and reduction results for $\mathrm{Cr}(\mathrm{VI})$ recombinant strains were tested from multiple measurements of the A600 and $\mathrm{Cr}(\mathrm{VI})$ reduction rates at different time points while the strains were exposed to different concentrations of $\mathrm{Cr}(\mathrm{VI})$, repeated measurement analysis of variance was chosen to investigate the difference in the overall change trend of the data. Factorial design may construct the cross-grouping of many factors and investigate the variations between each factor level and the interaction between factors, which satisfy our requirements. Therefore, the impact of $\mathrm{pH}$ and temperature on $\mathrm{Cr}(\mathrm{VI})$ reduction by the recombinant strains was tested through a factor design analysis of variance. The effects of metal ions and small molecules were tested via single-factor analysis of variance.

\section{RESULTS AND DISCUSSION}

\section{Construction of Recombinant Strains}

The construction process for recombinant plasmids is shown in Figure 1, and the PCR products of the recombinant strains were detected by $1.5 \%$ agarose gel electrophoresis. Agarose gel electrophoresis showed that target genes were successfully amplified from recombinant strains 2987, 3015, 0415, and 3237, with lengths of approximately 500,650,600, and $700 \mathrm{bp}$, respectively. The DNA sequencing results of recombinant strains 2987, 3015, 0415 and 3237 revealed that the sequences were the same as the target gene. Agarose gel electrophoresis results were strongly consistent with DNA sequencing results, indicating that the target gene was accurately linked to and transformed with the vector plasmid, and the recombinant strains had been constructed successfully.

\section{Expression and Localization of Recombinant Proteins}

Recombinant protein expression is shown in Figure 2. Protein bands of approximately $22,28,30$, and $35 \mathrm{kDa}$ were apparent in recombinant strains 2987, 3015, 0415, and 3237, respectively. The results demonstrated successful induction and expression of recombinant proteins. However, the molecular weights of the proteins derived by SDS-PAGE were approximately $2 \mathrm{kDa}$ larger than their theoretical values (2987: $20 \mathrm{kDa}, 3015: 28 \mathrm{kDa}$, 0415: $28 \mathrm{kDa}$, and 3237: $34 \mathrm{kDa}$ ). The reason for this was that the His-tag molecular weight in the pET-30a (+) plasmid vector.

The target protein bands of all recombinant strains were detected in supernatant and precipitation, although in varied proportions. Target protein 2987 was primarily detected in supernatant, whereas target proteins 3015, 0415, and 3237 were found in a combination of supernatant and precipitation, but the protein concentration of 3015 and 3237 was much greater than that of 3237. Li et al. (Mengke et al., 2019) discovered that the primary components of supernatant were intracellular soluble chemicals, whereas the primary components of precipitation were cell membrane and insoluble proteins. Kaur et al. (2018) also discovered that high-level recombinant protein expression usually resulted in the accumulation of insoluble aggregated folded intermediates in the cytoplasm as inclusion bodies. To summarize, all recombinant proteins were soluble proteins, but some of them might exist as inclusion bodies because of overexpression. These results were consistent with previous genomic (Li et al., 2021) and proteome (data being submitted) analyses.

\section{Resistance to $\mathrm{Cr}(\mathrm{Vl})$}

As shown in Figure 3, the resistance of all strains to $\mathrm{Cr}(\mathrm{VI})$ followed the same pattern. As the concentration of $\mathrm{Cr}(\mathrm{VI})$ increased, the growth of the strains was impaired to some extent when compared to the $\mathrm{Cr}(\mathrm{VI})$-free group, obtaining the same results as Igiri et al. (2018). At $400 \mathrm{mg} / \mathrm{L}$ and $800 \mathrm{mg} / \mathrm{L}$, the growth of all strains was sluggish in comparison to those without $\mathrm{Cr}(\mathrm{VI})(p<0.05)$. Clear signs of sluggish growth were found in recombinant strain 3237 at $50 \mathrm{mg} / \mathrm{L} \mathrm{Cr}(\mathrm{VI})$, whereas in recombinant strains 3015 and 0415 at $100 \mathrm{mg} / \mathrm{L} \mathrm{Cr}(\mathrm{VI})$, and in recombinant strain 2987 at $200 \mathrm{mg} / \mathrm{L} \mathrm{Cr}(\mathrm{VI})$ same as M52 $(p<0.05)$. Furthermore, the growth of all strains at various concentrations of $\mathrm{Cr}(\mathrm{VI})$ is shown in Supplementary Figure S1. The results revealed that $800 \mathrm{mg} / \mathrm{L} \mathrm{Cr}(\mathrm{VI})$ strongly inhibited the growth of all strains, indicating that the minimum inhibitory concentration of M52 and the recombinant strains was the same, which was $800 \mathrm{mg} / \mathrm{L} \mathrm{Cr}(\mathrm{VI})$. However, at $100 \mathrm{mg} / \mathrm{L} \mathrm{Cr}(\mathrm{VI})$, recombinant strains did not grow as well as M52 except 2987 (Supplementary Figure S1b; $p<0.05)$. These results indicated that the tolerance of the strains to $\mathrm{Cr}(\mathrm{VI})$ was M52 $\approx 2987>3015 \approx 0415>3237$, which suggesting that these four functional genes may play a protective role in M52 surviving, allowing the strain to tolerate $\mathrm{Cr}(\mathrm{VI})$, with orf2987 having the most protective effect. However, this protective effect might not be attributable to the fact that orf2987 was a chromeresistant gene, but rather to its great capacity as a chromereduction gene, therefore, the specific gene function must be further confirmed by chromium reduction determination. Considering the growth of strains, $100 \mathrm{mg} / \mathrm{L} \mathrm{Cr}(\mathrm{VI})$ was chosen as the intervention condition for the subsequent experiments.

\section{Reduction of $\mathrm{Cr}(\mathrm{VI})$}

Increasing the concentration of $\mathrm{Cr}(\mathrm{VI})$ inhibited the reduction efficiency of recombinant strains to some extent (Figure 4). Recombinant strain 2987, which was identical to M52 in reduction efficiency, can completely reduce $\mathrm{Cr}(\mathrm{VI})$ at concentrations of $50 \mathrm{mg} / \mathrm{L}$ and $100 \mathrm{mg} / \mathrm{L} \mathrm{Cr}(\mathrm{VI})$, but the reduction rate at $200 \mathrm{mg} / \mathrm{L}$ $\mathrm{Cr}(\mathrm{VI})$ was much lower $(p<0.05)$. While the reduction efficiency of recombinant strain 3015 was higher at low concentrations of $\mathrm{Cr}(\mathrm{VI})$ (50 and $100 \mathrm{mg} / \mathrm{L}$ ), it was still not as good as 2987 $(p<0.05)$, and the other two recombinant strains began to show signs of inhibition at $100 \mathrm{mg} / \mathrm{L} \mathrm{Cr}(\mathrm{VI})(p<0.05)$. Except for 2987, the reduction percentage of M52 was higher than that of the 


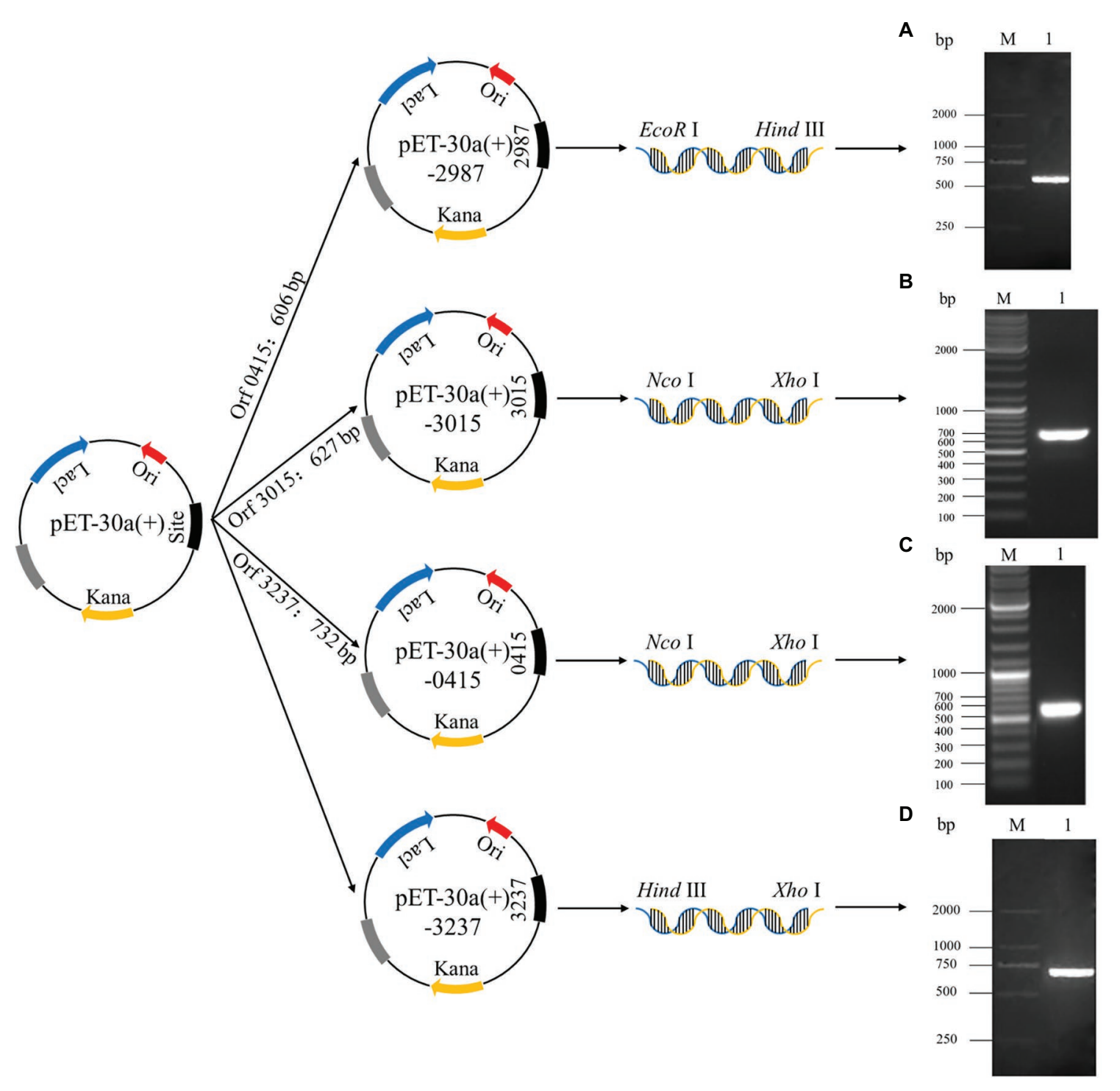

FIGURE 1 | The establishment process of recombinant plasmids pET-30a (+)-2987, pET-30a (+)-3015, pET-30a (+)-0415 and pET-30a (+)-3237 and the analysis of the PCR products of target genes by 1.5\% agarose gel electrophoresis. M: Marker. 1: Target genes 2987 (A), 3015 (B), 0415 (C) and 3237 (D).

recombinant strains in 50, 100 and $200 \mathrm{mg} / \mathrm{L} \mathrm{Cr}(\mathrm{VI})(p<0.05)$, as shown in Supplementary Figure S2, but there was no difference at high concentrations ( 400 and $800 \mathrm{mg} / \mathrm{L} ; p>0.05$ ). For the recombinant strains, there was no difference in the reduction percentage at an early stage $(p>0.05)$, which might be attributed to the need for recombinant strains to consume part of the protein to tolerate $\mathrm{Cr}(\mathrm{VI})$ and adapt to the $\mathrm{Cr}(\mathrm{VI})$-containing environment and then use the excess protein to reduce $\mathrm{Cr}(\mathrm{VI})$ to $\mathrm{Cr}$ (III). After $12 \mathrm{~h}$ of cultivation, recombinant strain 2987 had a slightly higher reduction percentage than 3015,0415 , and $3237(p<0.05)$. These results indicated that the reduced ability of the strains to $\mathrm{Cr}(\mathrm{VI})$ was $\mathrm{M} 52 \approx 2987>3015>0415 \approx 3237$, suggesting that these four functional genes, among which orf 2987 had the greatest reducing capability, might play a role in reducing $\mathrm{Cr}(\mathrm{VI})$ in M52. However, when combined with the results of the $\mathrm{Cr}(\mathrm{VI})$ tolerance analysis for recombinant strains, orf3015, orf0415, and orf3237 were not substantially different from orf2987 in $\mathrm{Cr}(\mathrm{VI})$ tolerance, but considerably different in $\mathrm{Cr}(\mathrm{VI})$ reduction. As a result, $\mathrm{Cr}(\mathrm{VI})$ tolerance of orf2987 might be due to its $\mathrm{Cr}(\mathrm{VI})$ reduction abilities, and orf2987 may be a chromereduction gene, which were consistent with previous genomic (Li et al., 2021) and proteome (data being submitted) analyses.

\section{SEM-EDS Analysis}

As shown in Figure 5, the recombinant strains 2987, 3015, 0415 and 3237 were all smooth, short, rod-shaped strains with blunted ends at $5000 \mathrm{x}$ magnification. However, the morphology of recombinant strains treated with $\mathrm{Cr}(\mathrm{VI})$ was altered in comparison to that of the $\mathrm{Cr}(\mathrm{VI})$-free group (control). After treatment with $\mathrm{Cr}(\mathrm{VI})$, the recombinant strain 0415 (Figure 5C) was converted from a short rod shape to a narrow rod shape, but the strain remained smooth, and no adhesion was formed between the 


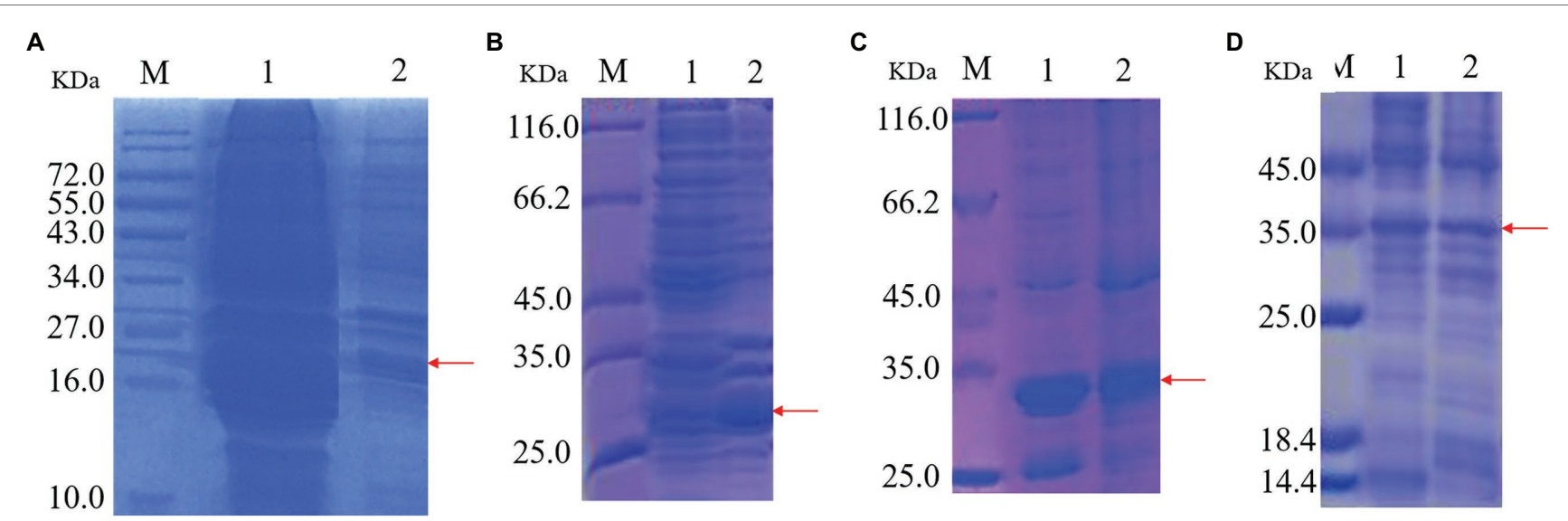

FIGURE 2 | SDS-PAGE of protein expression induced by recombinant strains 2987 (A), 3015 (B), 0415 (C) and 3237 (D). M: Marker. 1: Supernatant 2: Precipitate.

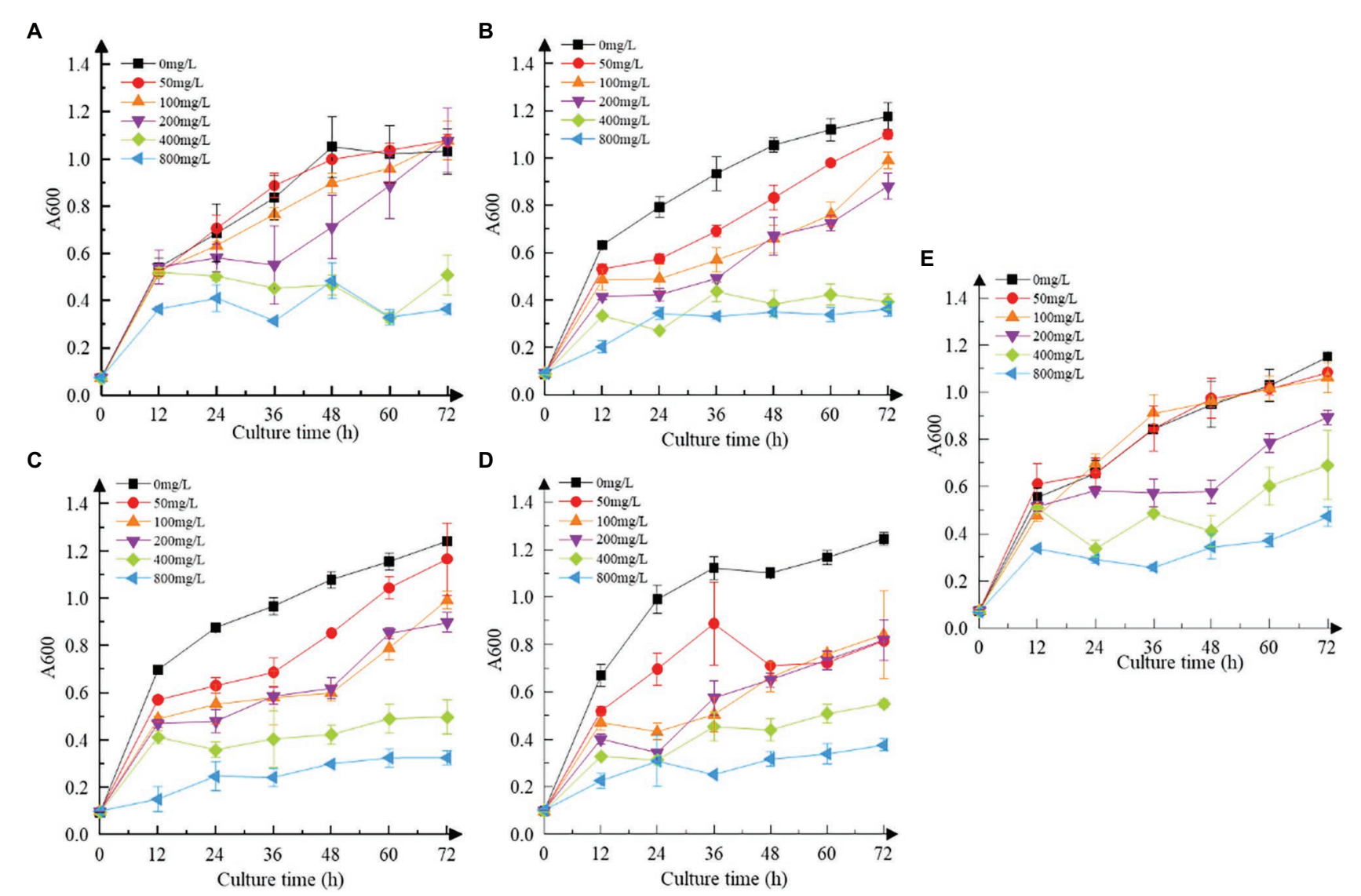

FIGURE 3 | Cr(VI) resistance of strains. (A) Recombinant strain 2987; (B) recombinant strain 3015; (C) recombinant strain 0415; (D) recombinant strain 3237; and (E) M52 (control). Date represent means \pm SD. All experiments were repeated three times.

strains. However, the morphology of recombinant strains 2987, 3015 and 3237 all changed significantly. There was no improvement in strain volume when recombinant strains 2987 (Figure 5A) and 3237 (Figure 5D) were treated with $\mathrm{Cr}(\mathrm{VI})$, but the surface of the strain became rough and the strains adhered to each other. The length of recombinant strain 3015 (Figure 5B) increased to $50 \mu \mathrm{m}$ after treatment with $\mathrm{Cr}(\mathrm{VI})$, and the strains exhibited a form of mutual adhesion. The morphology of the recombinant strains changed under chromium stress, and its surface became rough instead of smooth, which might be due to chromium reduction product adsorption on its surface. In response to the danger of toxic pollutants, Karthik (Karthik et al., 2017) discovered 


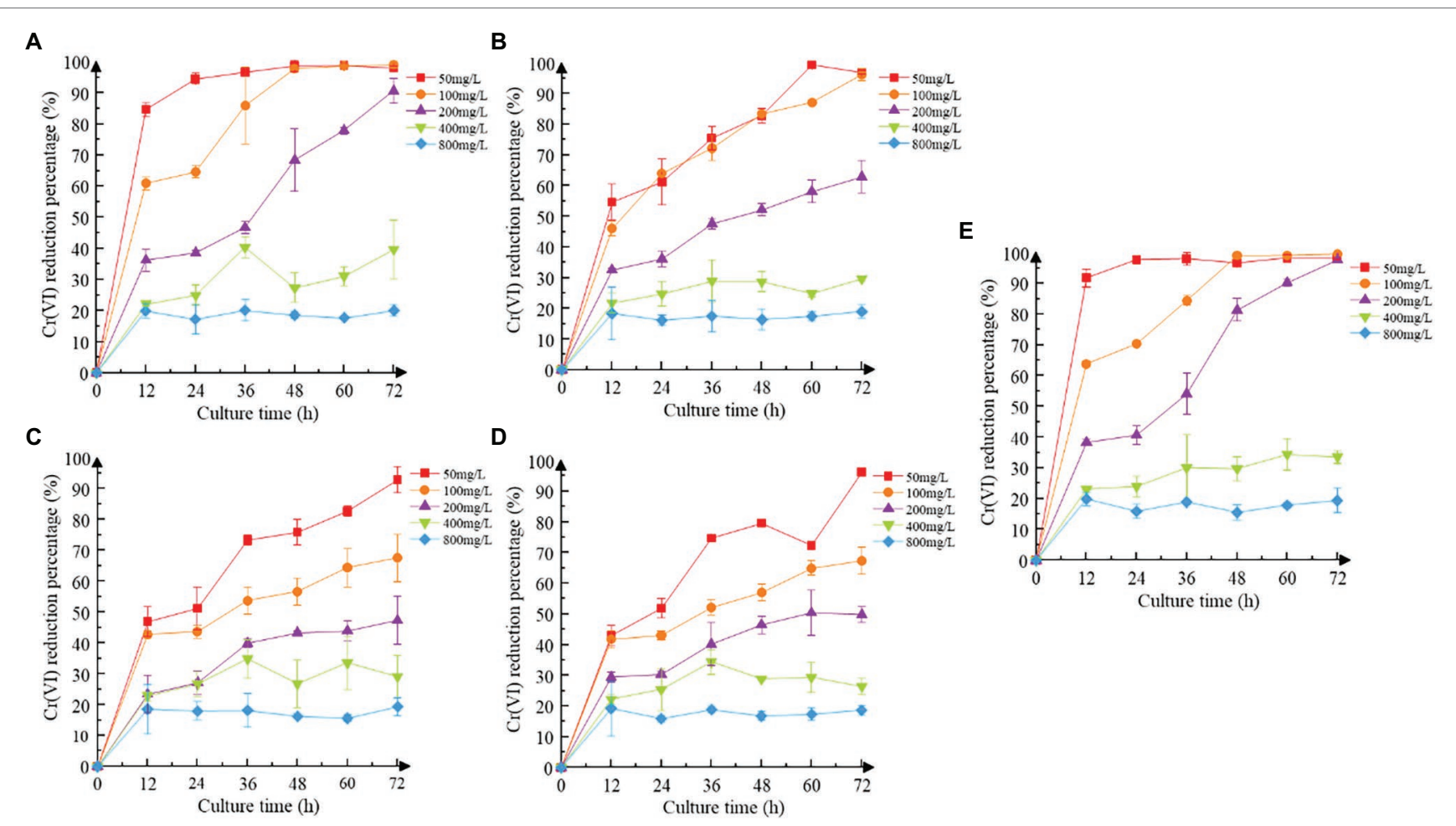

FIGURE 4 | Cr(VI) reduction of strains. (A) Recombinant strain 2987; (B) recombinant strain 3015; (C) recombinant strain 0415; (D) recombinant strain 3237; and (E) M52 (control). Date represent means \pm SEM. All experiments were repeated three times.

the similar phenomenon in the Cellulosimicrobium funkei strain AR8 that bacteria would congregate together, and undertake morphological modifications to defend themselves. The SEM micrograph showed that recombinant strain 0415 was the least affected by $\mathrm{Cr}(\mathrm{VI})$, while recombinant strains 2987 and 3237 were the most severely affected. With the exception of 2987, the resistance of recombinant strains to $\mathrm{Cr}(\mathrm{VI})$ was consistent with the previous results of $3015 \approx 0415>3237$. This showed that while 2987 would tolerate and reduce $\mathrm{Cr}$ (VI) well within $72 \mathrm{~h}$, the strain damage was severe and might not have a long-term sustained recovery effect. These results supported our hypothesis that the primary function of orf2987 in M52 was to decrease $\mathrm{Cr}(\mathrm{VI})$ rather than to protect the strain. The recombinant strain 0415 exhibited the greatest capacity to resist $\mathrm{Cr}(\mathrm{VI})$ in terms of strain shape and structure. Therefore, combined with the results of $\mathrm{Cr}(\mathrm{VI})$ tolerance and reduction experiment, orf0415 may primarily play the protective function of $\mathrm{Cr}(\mathrm{VI})$ tolerance in $\mathrm{M} 52$, rather than the reduction role, which may be mostly performed by orf 2987 .

The EDS spectra of the elementary analysis of the recombinant strains before and after the reduction of $\mathrm{Cr}(\mathrm{VI})$ are shown in Figure 5. $\mathrm{Cr}(\mathrm{VI})$ was not detected before the treatment (control), and characteristic peaks of $\mathrm{Cr}$ were observed after reduction in all recombinant strains, which was consistent with the findings of Vidyalaxmi et al. (2019). Some coexisting chemical elements have been observed, including $\mathrm{C}, \mathrm{O}, \mathrm{Na}, \mathrm{Mg}, \mathrm{Al}, \mathrm{Si}, \mathrm{S}$, and $\mathrm{Ca}$, similar to Zeng et al. (2019). EDS element mapping (Supplementary Figure S3) revealed that the surface of all recombinant strains consisted mostly of $\mathrm{C}$ and $\mathrm{O}$ elements that were scattered throughout the growth of the strain and contained a trace of Cr. As a result, it was suggested that, the recombinant strains had a weak capacity to adsorb Cr. This might be because the surface of E. coli contains hydroxyl, carbonyl, carboxyl, sulfonate, amide, imidazole, phosphonate, and phosphate diester functional groups, which can interact with metal ions (Quintelas et al., 2009). However, whether the $\mathrm{Cr}$ adsorbed was $\mathrm{Cr}(\mathrm{VI})$ or Cr(III) must be determined using XRD, FT-IR, and XPS.

\section{XRD, FT-IR, and XPS Analysis}

Cr was observed on the surface of all recombinant strains following treatment with $\mathrm{Cr}(\mathrm{VI})$, as shown in Figures 6A1-D1, but the specific changes were different. The XRD diffraction peak (Supplementary Figure S4a) with recombinant strain 2987 was concave at $28.11^{\circ}$, with the diffraction peak occurring at $21.82^{\circ}$, suggesting that the surface structure of the strain had changed. The FT-IR results (Supplementary Figure S4b), an important method for defining functional groups that interact with metals and strains (Karthik et al., 2017), showed that the peaks of recombinant strain 2987 at 992, 1087, 1237 and $1358 \mathrm{~cm}^{-1}$ vanished after $\mathrm{Cr}(\mathrm{VI})$ treatment, while peaks at 2859 and $2930 \mathrm{~cm}^{-1}$ shifted, indicating that the strain would reduce $\mathrm{Cr}(\mathrm{VI})$ by surface phosphate groups, peptide bonds, carboxyl groups, C-N bonds, and $\mathrm{N}-\mathrm{H}$ bonds, while alkyl and hydroxyl groups combined with $\mathrm{Cr}(\mathrm{VI})$. Further XPS analysis, including the $\mathrm{C}$ peak analysis of the strain without $\mathrm{Cr}(\mathrm{VI})$ and $\mathrm{Cr}(\mathrm{VI})$ culture, is shown in Supplementary Figure S5a. The characteristic peaks of C 1 s were $284.74 \mathrm{eV}(\mathrm{C}-\mathrm{C}$ or $\mathrm{C}-\mathrm{H}), 285.81 \mathrm{eV}(\mathrm{C}=\mathrm{N})$ and $287.90 \mathrm{eV}(\mathrm{C}=\mathrm{O})$. 
A
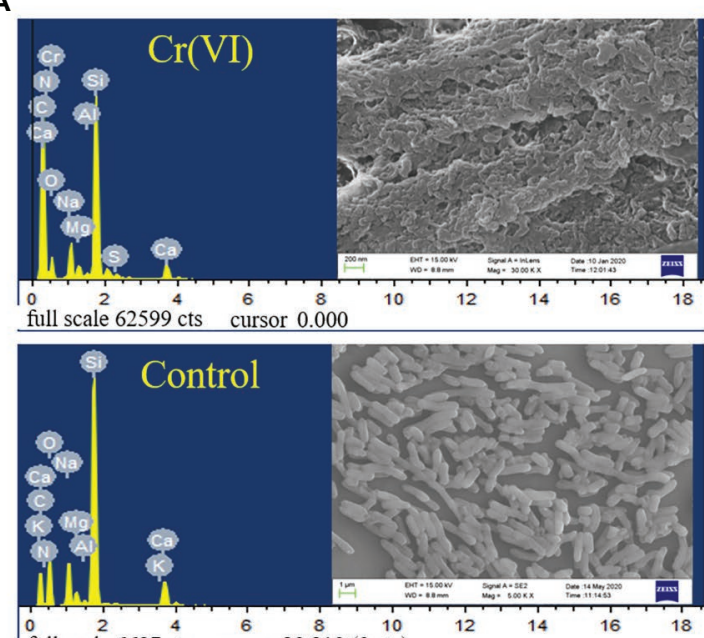

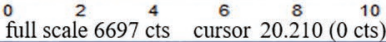

C
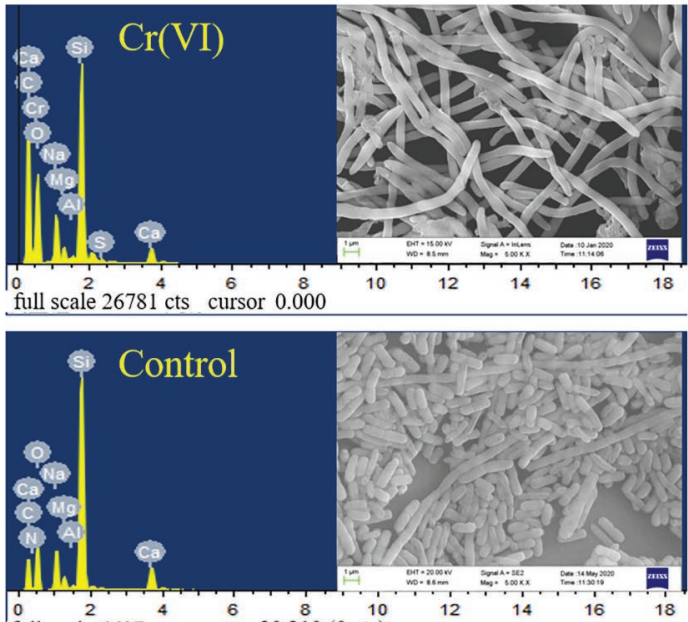
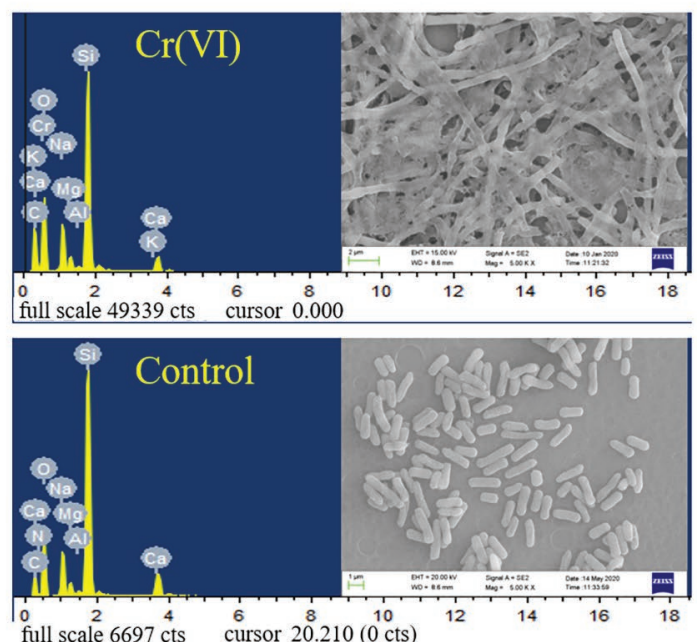

D
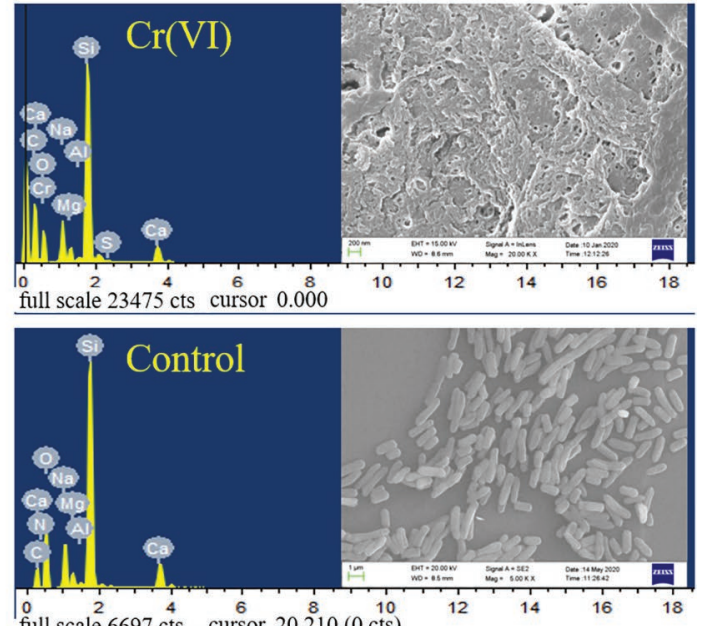

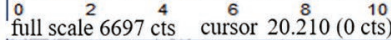

FIGURE 5 | SEM images and EDS analysis of recombinant strains 2987 (A), 3015 (B), 0415 (C) and 3237 (D). LB medium containing 100 mg/L Cr(VI) was used as the experimental group, and medium without $100 \mathrm{mg} / \mathrm{L} \mathrm{Cr}(\mathrm{VI})$ was used as the control.

The peaks of O 1s (Supplementary Figure S5b) were $531.14 \mathrm{eV}$ $(\mathrm{O}=\mathrm{C})$ and $532.24 \mathrm{eV}(\mathrm{C}-\mathrm{OH})$. The characteristic peak results of C $1 \mathrm{~s}$ and O1s are consistent with those of Li et al. (2016). The weak peaks of $\mathrm{Cr} 2 \mathrm{p}$ and $\mathrm{Cr} 3 \mathrm{p}$ (Figure 6A2) were situated at 577.61 and $587.40 \mathrm{eV}$, which were compatible with the $\mathrm{Cr}$ (III) characteristic peaks (Cheng et al., 2016). The results indicated that the recombinant strain 2987 reduced $\mathrm{Cr}(\mathrm{VI})$ to $\mathrm{Cr}$ (III) by providing electrons from amide, carboxyl and hydroxyl functional groups, and reduction product existed on the cell surface. But XRD diffraction peaks are inconsistent with characteristic peaks such as $\mathrm{Cr}_{2} \mathrm{O}_{3}, \mathrm{Cr}(\mathrm{OH})_{3}$ and other inorganic crystalline compound (Karthik et al., 2017; Tan et al., 2020), suggesting that the reduced products may reside on the surface of the strain in the form of organic complexes that require further identification ( $\mathrm{Li}$ et al., 2019). Our previous research discovered that M52 may engage in $\mathrm{Cr}$ (III) binding via amide, carboxyl, hydroxyl, alkyl and phosphorylated functional groups on the cell surface ( $\mathrm{Li}$ et al., 2021). Similar to our results, Huang et al. (2021) also found that hydroxyl, carboxyl and phosphorylated functional groups were involved in $\mathrm{Cr}$ (III) binding in Sporosarcina Saromensis W5. The recombinant strain 2987 possessed amide, carboxyl and hydroxyl, but lacked alkyl and phosphate functional groups. The above results indicated that orf2987 was important in reducing $\mathrm{Cr}(\mathrm{VI})$ by M52, but the reduction process was not solely dominated by orf 2987 .

The XRD results of recombinant strains 3015 (Supplementary Figure S4c), 0415 (Supplementary Figure S4e) and 3237 (Supplementary Figure S4g) were altered after treatment with $\mathrm{Cr}(\mathrm{VI})$. The diffraction peaks of recombinant strain 3015 and 0415 disappeared at $10.74^{\circ}$ and $21.82^{\circ}$, while a new diffraction peak of $17.50^{\circ}$ appeared in recombinant strain 3015. But recombinant strain 3237 was different, since the diffraction peaks at $10.74^{\circ}$ and $25.14^{\circ}$ vanished. These results suggested that the surface structure of the three recombinant strains had changed. But these peaks are not consistent with $\mathrm{Cr}$ (III) crystalline compound characteristic peaks. The FT-IR spectrum showed that the peaks of recombinant strain 3015 (Supplementary Figure S4d) at 997, 

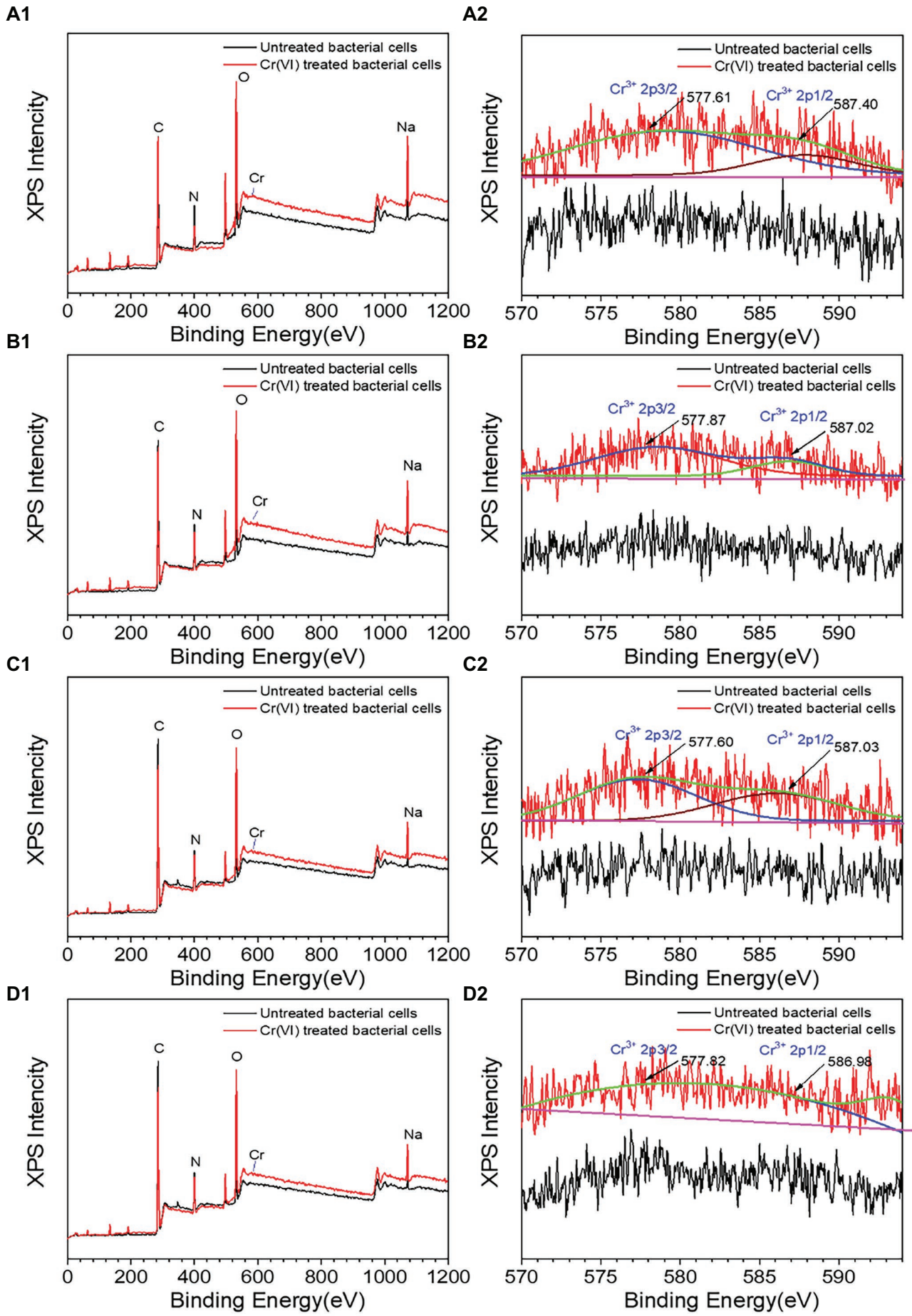

FIGURE 6 | XPS spectra of recombinant strains 2987 (A1,A2), 3015 (B1,B2), 0415 (C1,C2), and 3237 (D1,D2). LB medium containing 100 mg/L Cr(VI) was used as the experimental group, and medium without $100 \mathrm{mg} / \mathrm{L} \mathrm{Cr}(\mathrm{VI})$ was used as the control.

$1,088,1,239,1,396$, and $1,451 \mathrm{~cm}^{-1}$ vanished after treatment with $\mathrm{Cr}(\mathrm{VI})$, recombinant strain 0415 (Supplementary Figure S4f) showed that the peaks at 987 and $1,082 \mathrm{~cm}^{-1}$ disappeared, and recombinant strain 3237 lack of peaks at 1,359 and $1,456 \mathrm{~cm}^{-1}$ in (Supplementary Figure $\mathbf{S 4 h}$ ), as well as a shift in the relative intensity of the peak at $2,931 \mathrm{~cm}^{-1}$. In order to better identify functional groups, XPS detection was used to showed that the characteristic peaks of recombinant strain 3015 (Supplementary Figures S5c,d) and 0415 (Supplementary Figures S5e,f) at C 1 s and O 1s were the same 
as those of 2987, and the characteristic peaks of $\mathrm{Cr} 2 \mathrm{p}$ and $\mathrm{Cr}$ $3 p$ showed that recombinant strains 3015 (Figure 6B2) and 0415 (Figure 6C2) could fit the characteristic peaks of $\mathrm{Cr}$ (III). The characteristic peaks of recombinant strain 3237 at $\mathrm{C} 1 \mathrm{~s}$ and $\mathrm{O}$ $1 \mathrm{~s}$ matched those of the other three recombinant strains, as shown in Supplementary Figures $\mathbf{S 4 g , h}$, but there was no characteristic $\mathrm{Cr}$ peak when fitting $\mathrm{Cr} 2 \mathrm{p}$ and $\mathrm{Cr} 3 \mathrm{p}$ (Figure 6D2). These results indicated that phosphate, alkyl, amide, carboxyl and hydroxyl were involved in the reduction of $\mathrm{Cr}(\mathrm{VI})$ and combination of $\mathrm{Cr}$ (III) in recombinant strain 3015 and 0415, but nitrate, amide, carboxyl and hydroxyl and alkyl only were involved in the reduction of $\mathrm{Cr}(\mathrm{VI})$ in recombinant strain 3237. The functional groups involved in the reduction of $\mathrm{Cr}(\mathrm{VI})$ and combination of $\mathrm{Cr}$ (III) in recombinant strains 3015 and 0415 were similar to M52 (Li et al., 2021), and these groups have been proven to have the same function in other strains (Chen et al., 2019; Kumar and Dwivedi, 2019; Huang et al., 2021). Alkyl and phosphate functional groups were lacked in the recombinant strain 2987 but were present in 3015 and 0415, which prompted that orf3015 and orf0415 might play a role in the binding reduction product of M52 alongside orf2987.

When the results of chromium tolerance, chromium reduction, and characterization analysis were combined, it was evident that the four functional genes did not adsorb $\mathrm{Cr}(\mathrm{VI})$, but rather reduced $\mathrm{Cr}(\mathrm{VI})$ before adsorbing its reduction product, with orf2987 mostly reducing $\mathrm{Cr}(\mathrm{VI})$ in M52 and orf0415 primarily protecting the strain. After reducing $\mathrm{Cr}(\mathrm{VI})$, the orf2987 and orf0415 may interact with the reduced products via amide, carboxyl, hydroxyl, alkyl, and phosphorylation functional groups. However, orf3015 and orf3237 played a weaker role in these processes. This implies that orf2987 and orf0415 were the main functional genes in M52. Therefore, in the subsequent experiments, we concentrated on the two recombinant strains 2987 and 0415 to investigate the best conditions for the expression of the 2987 and 0415 proteins.

\section{Effect of $\mathrm{pH}$ and Temperature on $\mathrm{Cr}(\mathrm{VI})$ Reduction}

The activity of reductase, the availability of heavy metal ions, and the active sites of heavy metal binding on the cell surface could all be affected by $\mathrm{pH}$ and temperature, reducing the effectiveness with which heavy metals are removed by microorganisms (Wu et al., 2019). At the same time, Khattar et al. (2014) proved that acidic conditions could impact the structure of microbial sulfate transporters, inhibiting the removal of $\mathrm{Cr}(\mathrm{VI})$ by strains. Many studies have investigated the effects of temperature or $\mathrm{pH}$ on the removal of heavy metals by bacteria as two separate parameters (Khattar et al., 2014; Wu et al., 2019). In this study, however, the factorial study revealed that $\mathrm{pH}$ and temperature influenced the reduction of $\mathrm{Cr}(\mathrm{VI})$ by all recombinant strains and that there was an association between the two $(p<0.05)$. Gruber et al. (2016) also discovered that considering temperature and $\mathrm{pH}$ independently will exaggerate their influence effect when compared to considering their interaction. This might be because when the temperature of an alkaline solution rises, the $K_{w}$ of the solution rises, causing the concentration of $c\left(\mathrm{H}^{+}\right)$in the solution to rise and the $\mathrm{pH}$ of the solution to decrease. The effect of $\mathrm{pH}$ and temperature on the reduction of $\mathrm{Cr}(\mathrm{VI})$ by strains must therefore be thoroughly explored. As shown in Figure 7, changing the $\mathrm{pH}$ and temperature had an influence
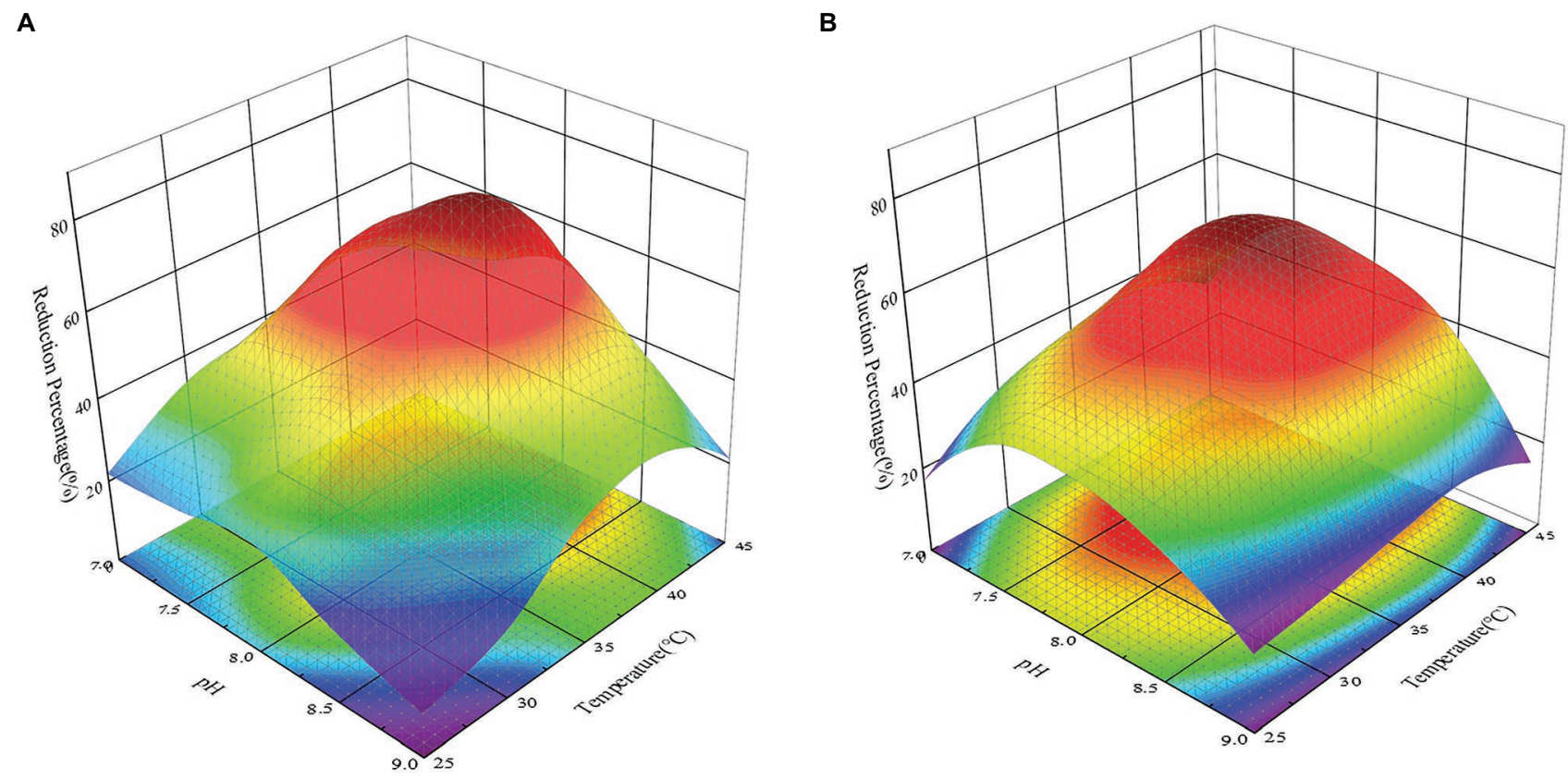

FIGURE 7 | Response surface 3D plot of pH versus temperature showing the effect of independent variables on the reduction of Cr(VI) by recombinant strains 2987 (A) and 0415 (B) at 48h. The higher the reduction rate is, the more dark red the color appears; the lower the reduction rate is, the more dark blue the color appears. Data represent means \pm SEM. All experiments were repeated three times. 
on the recombinant strains 2987 and 0415. Previous study had showed that M52 could resist $\mathrm{pH} 7.0-8.5$ and temperatures $25-35^{\circ} \mathrm{C}$, with $\mathrm{pH} 8.0$ and temperatures $35^{\circ} \mathrm{C}$ being the optimal $\mathrm{pH}$ and temperature (Zhao et al., 2016). Recombinant strains 2987 and 0415 were able to survive at $\mathrm{pH} 7.0-9.0$ and temperatures $25-45^{\circ} \mathrm{C}$, with $7.5-8.5$ and $37^{\circ} \mathrm{C}$ being the optimum $\mathrm{pH}$ and temperature, respectively, and the former showed higher environmental tolerance than M52.

From a different angle, the reduction percentage of $\mathrm{Cr}(\mathrm{VI})$ by recombinant strains was lower at both ends of the $\mathrm{pH}$ and temperature gradient (Figure 7). From the perspective of $\mathrm{pH}$, this may be due to an inappropriate acid-based environment that harmed growth, metabolic activity, and $\mathrm{Cr}(\mathrm{VI})$-reducing recombinant strains (Xu et al., 2012). High temperatures could induce changes in ribosomal conformation and loss of $\mathrm{Cr}(\mathrm{VI})$ reductase activity, as well as changes in membrane structure or protein synthesis inactivation, while low temperatures considerably decrease cell fluidity, preventing the transport system from functioning (Narayani and Shetty, 2013; Das et al., 2014; Karthik et al., 2017).

\section{Effect of Metal Ions and Small Molecules on $\mathrm{Cr}(\mathrm{VI})$ Reduction}

With the exception of $\mathrm{Cr}(\mathrm{VI})$, certain other heavy metal ions and small molecules may also affect the ability of recombinant strains to reduce $\mathrm{Cr}(\mathrm{VI})$ in industrial wastewater (Wani et al., 2019; Tan et al., 2020). $\mathrm{Cu}^{2+}, \mathrm{Mn}^{2+}$, and $\mathrm{Fe}^{2+}$ are frequently present with $\mathrm{Cr}(\mathrm{VI})$ in wastewater from the electroplating and mining industries, whereas SDS, as detergent and textile auxiliaries, is present with $\mathrm{Cr}(\mathrm{VI})$ in textile wastewater (Shadrunova and Orekhova, 2015; Khosravi et al., 2020). These heavy metal ions and small molecules may impair the recombinant strain's capacity to remove $\mathrm{Cr}(\mathrm{VI})$ in practice, thus it is critical to test the impact of $\mathrm{Cr}(\mathrm{VI})$ removal prior to application. To further improve the reaction conditions, the effects of typical heavy metal ions such as $\mathrm{Cu}^{2+}, \mathrm{Mn}^{2+}$ and $\mathrm{Fe}^{2+}$, as well as small molecules, were investigated on the reduction effect of $\mathrm{Cr}(\mathrm{VI})$. The recombinant strain 2987 and 0415 rapidly reduced $\mathrm{Cr}(\mathrm{VI})$ by $100 \mathrm{mg} / \mathrm{L}$ over time, with the rates reaching a limit of $48 \mathrm{~h}$. It was clear from the control that $\mathrm{Cu}^{2+}, \mathrm{Fe}^{2+}$, and $\mathrm{Mn}^{2+}$ could all support the reduction of $\mathrm{Cr}(\mathrm{VI})$ to differing degrees, with $\mathrm{Cu}^{2+}$ having the greatest promotional effect ( $p<0.05$; Figure 8). Recombinant strain 2987 and 0415 completely reduced $100 \mathrm{mg} / \mathrm{L} \mathrm{Cr}(\mathrm{VI})$ by adding $\mathrm{Cu}^{2+}$. Tanrikulu et al. (2011) showed that $\mathrm{Cu}^{2+}$ was an essential component of antioxidant enzymes such as catalase and superoxide dismutase as well as the prosthetic group of many reductases (Abe et al., 2001). In addition, $\mathrm{Xu}$ et al. (2015) also observed that $\mathrm{Cu}^{2+}$ was an essential component of electron transfer in the oxidative respiratory system. Therefore, it was inferred that $\mathrm{Cu}^{2+}$ could improve the $\mathrm{Cr}(\mathrm{VI})$-reduction capacity by enhancing the resistance of the recombinant strains to $\mathrm{Cr}(\mathrm{VI})$ and the electron transfer efficiency. $\mathrm{Fe}^{2+}$ and $\mathrm{Mn}^{2+}$ could also promote $\mathrm{Cr}(\mathrm{VI})$ reduction by recombinant strain 2987 and 0415, but the strength of the promotion varied by strain. The promotional impact of metal ions on recombinant strain 0415 was $\mathrm{Cu}^{2+}>\mathrm{Mn}^{2+}>\mathrm{Fe}^{2+}(p<0.05)$, whereas $\mathrm{Cu}^{2+}>\mathrm{Fe}^{2+}>\mathrm{Mn}^{2+}$ was the impact on recombinant strains $2987(p<0.05)$. Bansal et al. (2019) assumed that $\mathrm{Fe}^{2+}$, as an electron donor, may play an important role in $\mathrm{Fe} / \mathrm{Cr}$ redox coupling. $\mathrm{Mn}^{2+}$ was nearly related to the cycle of every other element and had an intimate relationship with the wellbeing, metabolism, and function of microorganisms (Hansel, 2017). Thus, $\mathrm{Fe}^{2+}$ and $\mathrm{Mn}^{2+}$ can serve as $\mathrm{Cr}(\mathrm{VI})$-reductase activators to promote the reduction of $\mathrm{Cr}(\mathrm{VI})$ by recombinant strains. In comparison to metal ions, SDS inhibited the reduction of $\mathrm{Cr}(\mathrm{VI})$ by recombinant strains, which was the same as the study of Wani et al. (2019). This may be because SDS could damage the cell wall and denature the protein (Krainer et al., 2020), affecting the resistance of the strain to $\mathrm{Cr}(\mathrm{VI})$ and the activity of $\mathrm{Cr}(\mathrm{VI})$ reductase. In general, $\mathrm{Cu}^{2+}, \mathrm{Fe}^{2+}$ and $\mathrm{Mn}^{2+}$ could increase the
A

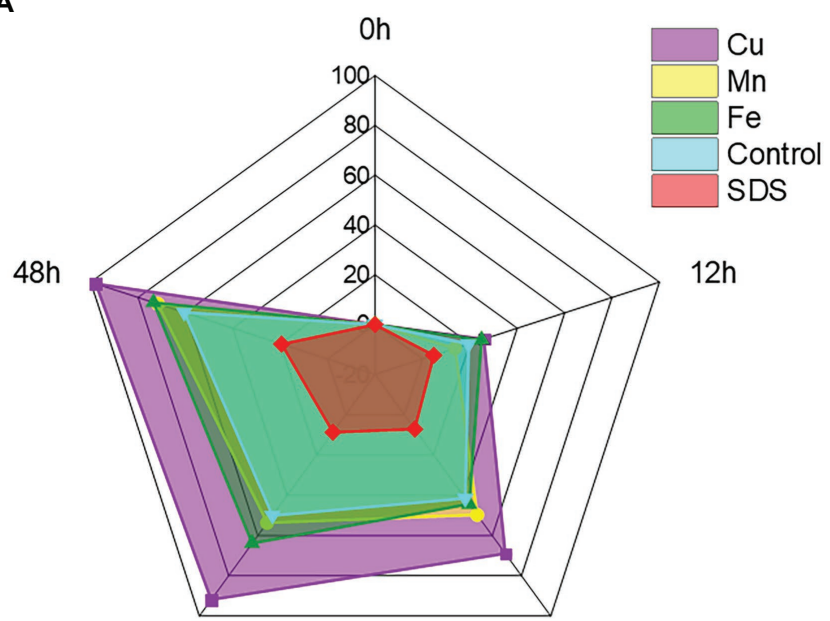

$36 \mathrm{~h}$

$24 \mathrm{~h}$
B

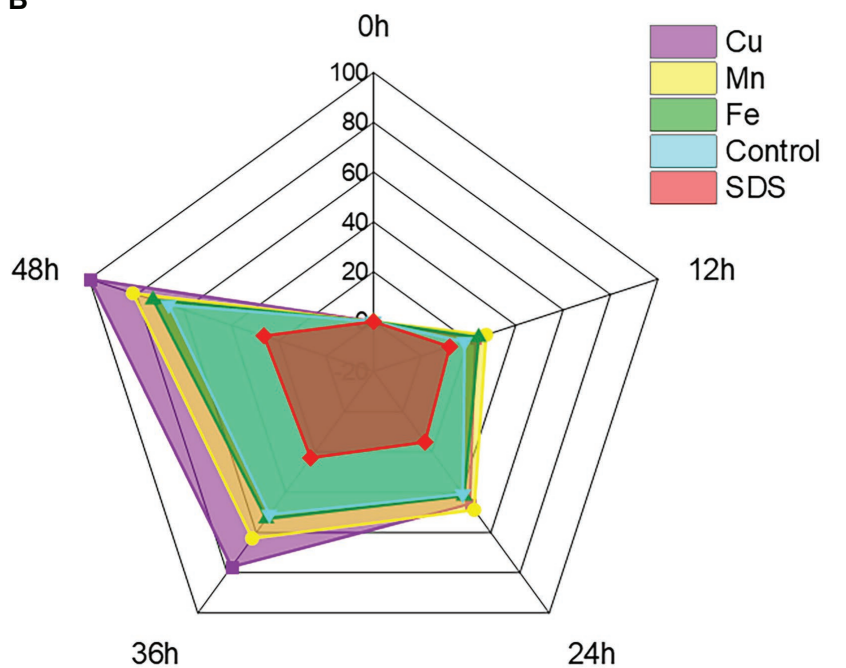

FIGURE 8 | Radar chart of metal ions and small molecules showing the effect on the reduction of Cr(VI) by recombinant strains 2987 (A) and 0415 (B). The shaded area is used to indicate the strain's ability to reduce $\mathrm{Cr}(\mathrm{VI})$. Data represent means $\pm \mathrm{SEM}$. All experiments were repeated three times. 
$\mathrm{Cr}(\mathrm{VI})$ reduction efficiency of the recombinant strains 2987 and 0415, with $\mathrm{Cu}^{2+}$ being the most effective, whereas SDS could decrease the $\mathrm{Cr}(\mathrm{VI})$ reduction efficiency of the recombinant strains 2987 and 0415.

\section{CONCLUSION}

This study confirmed that functional gene segments orf2987, orf3015, orf0415, and orf3237 all had the ability to tolerate and reduce $\mathrm{Cr}(\mathrm{VI})$, with orf2987 exhibiting primarily reduction characteristics, orf0415 exhibiting primarily tolerance characteristics, while orf3015 and orf3237 exhibiting only minor effects on both aspects. Recombinant strains 2987 and 0415 could reduction $\mathrm{Cr}(\mathrm{VI})$ via amide, carboxyl, hydroxyl, alkyl and phosphorylation functional, and both could combine with the reduced product, $\mathrm{Cr}$ (III) organic complexes, on the cell surface, with 2987 being more competent. The optimal pH of recombinant strains 2987 and 0415 was 7.5-8.5, while the optimal temperature was $37^{\circ} \mathrm{C}$, demonstrating higher environmental tolerance than $\mathrm{M} 52 . \mathrm{Cu}^{2+}, \mathrm{Fe}^{2+}$, and $\mathrm{Mn}^{2+}$ promote the strains, with $\mathrm{Cu}^{2+}$ being the most, whilst SDS may inhibit them. Although this research provided a good theoretical foundation for investigating the functional genes and reduction mechanism of M52 to reduce $\mathrm{Cr}(\mathrm{VI})$, it is likely that a single gene fragment will be unable to replace the combined effect of numerous gene clusters. It also indicates that further research may be conducted to create recombinant strains with combined effectiveness to $\mathrm{Cr}(\mathrm{VI})$ reduction efficiency.

\section{DATA AVAILABILITY STATEMENT}

The raw data supporting the conclusions of this article will be made available by the authors, without undue reservation.

\section{REFERENCES}

Abe, F., Miura, T., Nagahama, T., Inoue, A., Usami, R., and Horikoshi, K. (2001). Isolation of a highly copper-tolerant yeast, Cryptococcus sp., from the Japan trench and the induction of superoxide dismutase activity by $\mathrm{Cu}^{2+}$. Biotechnol. Lett. 23, 2027-2034. doi: 10.1023/A:1013739232093

Agrawal, A., Kumar, V., and Pandey, B. D. (2006). Remediation options for the treatment of electroplating and leather tanning effluent containing chromium-a review. Miner. Process. Extr. Metall. Rev. 27, 99-130. doi: 10.1080/08827500600563319

Banerjee, S., Misra, A., Chaudhury, S., and Dam, B. (2019). A Bacillus strain TCL isolated from Jharia coalmine with remarkable stress responses, chromium reduction capability and bioremediation potential. J. Hazard. Mater. 367, 215-223. doi: 10.1016/j.jhazmat.2018.12.038

Bansal, N., Coetzee, J. J., and Chirwa, E. M. N. (2019). In situ bioremediation of hexavalent chromium in presence of iron by dried sludge bacteria exposed to high chromium concentration. Ecotoxicol. Environ. Saf. 172, 281-289. doi: 10.1016/j.ecoenv.2019.01.094

Barrera-Diaz, C. E., Lugo-Lugo, V., and Bilyeu, B. (2012). A review of chemical, electrochemical and biological methods for aqueous $\mathrm{Cr}$ (VI) reduction. J. Hazard. Mater. 223-224, 1-12. doi: 10.1016/j. jhazmat.2012.04.054

Bharagava, R. N., and Mishra, S. (2018). Hexavalent chromium reduction potential of Cellulosimicrobium sp. isolated from common effluent treatment

\section{AUTHOR CONTRIBUTIONS}

QA: writing-original draft, formal analysis, validation, and visualization. MZ: conceptualization, investigation, validation, and visualization. DG and CF: methodology and data curation. GW and HX: validation and visualization. JL: validation and investigation. WZ and YL: investigation. XC: methodology. WY: validation. RZ: conceptualization, methodology, resources, supervision, project administration, and writing-review and editing. All authors contributed to the article and approved the submitted version.

\section{FUNDING}

This work was supported by the National Natural Science Foundation of China (NSFC No. 81673129), the Education Scientific Research Project of Young Teachers in Fujian Province (No. JAT160001), and the College Student Innovation and Entrepreneurship Training Program Support Project of Xiamen University (No. 2019X0528).

\section{ACKNOWLEDGMENTS}

The authors would like to express their gratitude to CF for his advice and guidance while this research and their heartfelt condolences for his passing.

\section{SUPPLEMENTARY MATERIAL}

The Supplementary Material for this article can be found online at: https://www.frontiersin.org/articles/10.3389/fmicb.2022.820657/ full\#supplementary-material

plant of tannery industries. Ecotoxicol. Environ. Saf. 147, 102-109. doi: 10.1016/j.ecoenv.2017.08.040

Bvrith, M. V., and Reddy, V. B. (2013). An overview on research trends in remediation of chromium. Res. J. Recent Sci. 2, 71-83.

Chen, S. H., Cheow, Y. L., Ng, S. L., and Ting, A. S. Y. (2019). Mechanisms for metal removal established via electron microscopy and spectroscopy: a case study on metal tolerant fungi Penicillium simplicissimum. J. Hazard. Mater. 362, 394-402. doi: 10.1016/j.jhazmat.2018.08.077

Cheng, W., Ding, C., Wang, X., Wu, Z., Sun, Y., Yu, S., et al. (2016). Competitive sorption of $\mathrm{As}(\mathrm{V})$ and $\mathrm{Cr}(\mathrm{VI})$ on carbonaceous nanofibers. Chem. Eng. J. 293, 311-318. doi: 10.1016/j.cej.2016.02.073

Das, S., Mishra, J., Das, S. K., Pandey, S., Rao, D. S., Chakraborty, A., et al. (2014). Investigation on mechanism of $\mathrm{Cr}(\mathrm{VI})$ reduction and removal by Bacillus amyloliquefaciens, a novel chromate tolerant bacterium isolated from chromite mine soil. Chemosphere 96, 112-121. doi: 10.1016/j. chemosphere.2013.08.080

Diaconu, M., Pavel, L. V., Hlihor, R. M., Rosca, M., Fertu, D. I., Lenz, M., et al. (2020). Characterization of heavy metal toxicity in some plants and microorganisms-a preliminary approach for environmental bioremediation. New Biotechnol. 56, 130-139. doi: 10.1016/j. nbt.2020.01.003

Garg, S. K., Tripathi, M., Singh, S. K., and Singh, A. (2013). Pentachlorophenol dechlorination and simultaneous $\mathrm{Cr}^{6+}$ reduction by Pseudomonas putida SKG-1 MTCC (10510): characterization of PCP dechlorination products, 
bacterial structure, and functional groups. Environ. Sci. Pollut. Res. Int. 20, 2288-2304. doi: 10.1007/s11356-012-1101-Z

Gruber, C., Kutuzov, I., and Ganor, J. (2016). The combined effect of temperature and $\mathrm{pH}$ on albite dissolution rate under far-from-equilibrium conditions. Geochim. Cosmochim. Acta 186, 154-167. doi: 10.1016/j. gca.2016.04.046

Gu, R., Gao, J., Dong, L., Liu, Y., Li, X., Bai, Q., et al. (2020). Chromium metabolism characteristics of coexpression of ChrA and ChrT gene. Ecotoxicol. Environ. Saf. 204:111060. doi: 10.1016/j.ecoenv.2020.111060

Guo, J., Lian, J., Xu, Z., Xi, Z., Yang, J., Jefferson, W., et al. (2012). Reduction of $\mathrm{Cr}(\mathrm{VI})$ by Escherichia coli BL21 in the presence of redox mediators. Bioresour. Technol. 123, 713-716. doi: 10.1016/j.biortech.2012.07.090

Hansel, C. M. (2017). "Manganese in marine microbiology," in Microbiology of Metal Ions. ed. R. K. Poole (London: Academic Press).

Harish, R., Samuel, J., Mishra, R., Chandrasekaran, N., and Mukherjee, A. (2012). Bio-reduction of Cr (VI) by exopolysaccharides (EPS) from indigenous bacterial species of Sukinda chromite mine, India. Biodegradation 23, 487-496. doi: 10.1007/s10532-011-9527-4

Huang, Y., Zeng, Q., Hu, L., Zhong, H., and He, Z. (2021). Bioreduction performances and mechanisms of $\mathrm{Cr}(\mathrm{VI})$ by Sporosarcina saromensis W5, a novel $\mathrm{Cr}(\mathrm{VI})$-reducing facultative anaerobic bacteria. J. Hazard. Mater. 413:125411. doi: 10.1016/j.jhazmat.2021.125411

Igiri, B. E., Okoduwa, S. I. R., Idoko, G. O., Akabuogu, E. P., Adeyi, A. O., and Ejiogu, I. K. (2018). Toxicity and bioremediation of heavy metals contaminated ecosystem from tannery wastewater: A review. J. Toxicol. 2018:2568038. doi: 10.1155/2018/2568038

Jaen, K. E., Velazquez, D., Delvigne, F., Sigala, J. C., and Lara, A. R. (2019). Engineering E. coli for improved microaerobic pDNA production. Bioprocess Biosyst. Eng. 42, 1457-1466. doi: 10.1007/s00449-019-02142-5

Jobby, R., Jha, P., Yadav, A. K., and Desai, N. (2018). Biosorption and biotransformation of hexavalent chromium [Cr(VI)]: a comprehensive review. Chemosphere 207, 255-266. doi: 10.1016/j.chemosphere.2018.05.050

Karthik, C., Barathi, S., Pugazhendhi, A., Ramkumar, V. S., Thi, N. B. D., and Arulselvi, P. I. (2017). Evaluation of Cr(VI) reduction mechanism and removal by Cellulosimicrobium funkei strain AR8, a novel haloalkaliphilic bacterium. J. Hazard. Mater. 333, 42-53. doi: 10.1016/j.jhazmat.2017.03.037

Kaur, J., Kumar, A., and Kaur, J. (2018). Strategies for optimization of heterologous protein expression in E. coli: roadblocks and reinforcements. Int. J. Biol. Macromol. 106, 803-822. doi: 10.1016/j.ijbiomac.2017.08.080

Ke, C., Zhao, C., Rensing, C., Yang, S., and Zhang, Y. (2018). Characterization of recombinant E. coli expressing arsR from Rhodopseudomonas palustris CGA009 that displays highly selective arsenic adsorption. Appl. Microbiol. Biotechnol. 102, 6247-6255. doi: 10.1007/s00253-018-9080-8

Khattar, J. I. S., Parveen, S., Singh, Y., Singh, D. P., and Gulati, A. (2014). Intracellular uptake and reduction of hexavalent chromium by the cyanobacterium Synechocystis sp. PUPCCC 62. J. Appl. Phycol. 27, 827-837. doi: 10.1007/s10811-014-0374-7

Khosravi, A., Karimi, M., Ebrahimi, H., and Ebrahimi, H. (2020). Sequencing batch reactor/nanofiltration hybrid method for water recovery from textile wastewater contained phthalocyanine dye and anionic surfactant. J. Environ. Chem. Eng. 8:103701. doi: 10.1016/j.jece.2020.103701

Krainer, G., Hartmann, A., Bogatyr, V., Nielsen, J., Schlierf, M., and Otzen, D. E. (2020). SDS-induced multi-stage unfolding of a small globular protein through different denatured states revealed by single-molecule fluorescence. Chem. Sci. 11, 9141-9153. doi: 10.1039/d0sc02100h

Kumar, V., and Dwivedi, S. K. (2019). Hexavalent chromium reduction ability and bioremediation potential of Aspergillus flavus CR500 isolated from electroplating wastewater. Chemosphere 237:124567. doi: 10.1016/j. chemosphere.2019.124567

Li, M., He, Z., Hu, Y., Hu, L., and Zhong, H. (2019). Both cell envelope and cytoplasm were the locations for chromium(VI) reduction by Bacillus sp. M6. Bioresour. Technol. 273, 130-135. doi: 10.1016/j. biortech.2018.11.006

Li, N., Pan, Y., Zhang, N., Wang, X., and Zhou, W. (2016). The bio-reduction of chromate with periplasmic reductase using a novel isolated strain Pseudoalteromonas sp. CF10-13. RSC Adv. 6, 106600-106607. doi: 10.1039/ c6ra16320c

Li, J., Tang, C., Zhang, M., Fan, C., Guo, D., An, Q., et al. (2021). Exploring the $\mathrm{Cr}(\mathrm{VI})$ removal mechanism of Sporosarcina saromensis M52 from a genomic perspective. Ecotoxicol. Environ. Saf. 225:112767. doi: 10.1016/j. ecoenv.2021.112767

Ma, Y., Zhong, H., and He, Z. (2019). Cr(VI) reductase activity locates in the cytoplasm of Aeribacillus pallidus BK1, a novel Cr(VI)-reducing thermophile isolated from Tengchong geothermal region, China. Chem. Eng. J. 371, 524-534. doi: 10.1016/j.cej.2019.04.085

Malaviya, P., and Singh, A. (2016). Bioremediation of chromium solutions and chromium containing wastewaters. Crit. Rev. Microbiol. 42, 607-633. doi: 10.3109/1040841X.2014.974501

Mengke, L., Yuting, Z., Yuting, H., Shuzhen, L., Liang, H., Hui, Z., et al. (2019). Exploration on the bioreduction mechanism of $\mathrm{Cr}(\mathrm{VI})$ by a grampositive bacterium: Pseudochrobactrum saccharolyticum W1. Ecotoxicol. Environ. Saf. 184:109636. doi: 10.1016/j.ecoenv.2019.109636

Narayani, M., and Shetty, K. V. (2013). Chromium-resistant bacteria and their environmental condition for hexavalent chromium removal: a review. Crit. Rev. Environ. Sci. Technol. 43, 955-1009. doi: 10.1080/10643389.2011.627022

Nayak, S., Rangabhashiyam, S., Balasubramanian, P., and Kale, P. (2020). A review of chromite mining in Sukinda Valley of India: impact and potential remediation measures. Int. J. Phytoremediation 22, 804-818. doi: 10.1080/15226514.2020.1717432

Quintelas, C., Rocha, Z., Silva, B., Fonseca, B., Figueiredo, H., and Figueiredo, H. (2009). Removal of cd(II), Cr(VI), $\mathrm{Fe}(\mathrm{III})$ and $\mathrm{Ni}(\mathrm{II})$ from aqueous solutions by an E. coli biofilm supported on kaolin. Chem. Eng. J. 149, 319-324. doi: 10.1016/j.cej.2008.11.025

Shadrunova, I. V., and Orekhova, N. N. (2015). A process for advanced recycling of water originating from mining operations, with metal recovery. Mine Water Environ. 34, 478-484. doi: 10.1007/s10230-015-0338-4

Stern, A. H. (2010). A quantitative assessment of the carcinogenicity of hexavalent chromium by the oral route and its relevance to human exposure. Environ. Res. 110, 798-807. doi: 10.1016/j.envres.2010.08.002

Tan, H., Wang, C., Zeng, G., Luo, Y., Li, H., and Xu, H. (2020). Bioreduction and biosorption of $\mathrm{Cr}(\mathrm{VI})$ by a novel Bacillus sp. CRB-B1 strain. J. Hazard. Mater. 386:121628. doi: 10.1016/j.jhazmat.2019.121628

Tanrikulu, A. C., Abakay, A., Evliyaoglu, O., and Palanci, Y. (2011). Coenzyme Q10, copper, zinc, and lipid peroxidation levels in serum of patients with chronic obstructive pulmonary disease. Biol. Trace Elem. Res. 143, 659-667. doi: 10.1007/s12011-010-8897-5

Thatoi, H., Das, S., Mishra, J., Rath, B. P., and Das, N. (2014). Bacterial chromate reductase, a potential enzyme for bioremediation of hexavalent chromium: a review. J. Environ. Manag. 146, 383-399. doi: 10.1016/j.jenvman.2014.07.014

Vidyalaxmi, Kaushik, G., and Raza, K. (2019). Potential of novel Dunaliella salina from sambhar salt lake, India, for bioremediation of hexavalent chromium from aqueous effluents: an optimized green approach. Ecotoxicol. Environ. Saf. 180, 430-438. doi: 10.1016/j.ecoenv.2019.05.039

Wani, P. A., Wahid, S., Khan, M. S. A., Rafi, N., and Wahid, N. (2019). Investigation of the role of chromium reductase for $\mathrm{Cr}$ (VI) reduction by Pseudomonas species isolated from Cr(VI) contaminated effluent. Biotechnol. Res. Innov. 3, 38-46. doi: 10.1016/j.biori.2019.04.001

Wu, M., Li, Y., Li, J., Wang, Y., Xu, H., and Zhao, Y. (2019). Bioreduction of hexavalent chromium using a novel strain CRB-7 immobilized on multiple materials. J. Hazard. Mater. 368, 412-420. doi: 10.1016/j.jhazmat.2019.01.059

Xia, S., Song, Z., Jeyakumar, P., Shaheen, S. M., Rinklebe, J., Ok, Y. S., et al. (2019). A critical review on bioremediation technologies for $\mathrm{Cr}(\mathrm{VI})$ contaminated soils and wastewater. Crit. Rev. Environ. Sci. Technol. 49, 1027-1078. doi: 10.1080/10643389.2018.1564526

Xu, W., Jian, H., Liu, Y., Zeng, G., Li, X., and Zhang, W. (2015). Bioreduction of chromate by an isolated Bacillus anthracis Cr-4 with soluble $\mathrm{Cr}$ (III) product. Water Air Soil Pollut. 226:82. doi: 10.1007/s11270-015-2356-Z

Xu, L., Luo, M., Jiang, C., Wei, X., Kong, P., Liang, X., et al. (2012). In vitro reduction of hexavalent chromium by cytoplasmic fractions of Pannonibacter phragmitetus LSSE-09 under aerobic and anaerobic conditions. Appl. Biochem. Biotechnol. 166, 933-941. doi: 10.1007/s12010-011-9481-y

Zeng, Q., Hu, Y., Yang, Y., Hu, L., Zhong, H., and He, Z. (2019). Cell envelop is the key site for $\mathrm{Cr}(\mathrm{VI})$ reduction by Oceanobacillus oncorhynchi W4, a newly isolated $\mathrm{Cr}(\mathrm{VI})$ reducing bacterium. J. Hazard. Mater. 368, 149-155. doi: 10.1016/j.jhazmat.2019.01.031

Zhao, R., Wang, B., Cai, Q., Li, X., Liu, M., Hu, D., et al. (2016). Bioremediation of hexavalent chromium pollution by Sporosarcina saromensis M52 isolated 
from offshore sediments in Xiamen, China. Biomed. Environ. Sci. 29, 127-136. doi: $10.3967 /$ bes 2016.014

Conflict of Interest: The authors declare that the research was conducted in the absence of any commercial or financial relationships that could be construed as a potential conflict of interest.

Publisher's Note: All claims expressed in this article are solely those of the authors and do not necessarily represent those of their affiliated organizations, or those of the publisher, the editors and the reviewers. Any product that may be evaluated in this article, or claim that may be made by its manufacturer, is not guaranteed or endorsed by the publisher.

Copyright (c) 2022 An, Zhang, Guo, Wang, Xu, Fan, Li, Zhang, Li, Chen, You and Zhao. This is an open-access article distributed under the terms of the Creative Commons Attribution License (CC BY). The use, distribution or reproduction in other forums is permitted, provided the original author(s) and the copyright owner(s) are credited and that the original publication in this journal is cited, in accordance with accepted academic practice. No use, distribution or reproduction is permitted which does not comply with these terms. 